\title{
Caleidoscópios de GÊNERO: Gênero e interseccionalidades NA DINÂMICA DAS RELAÇõES SOCIAIS ${ }^{1}$
}

\author{
Cecilia M. B. Sardenberg ${ }^{2}$
}

\begin{abstract}
Resumo
Neste trabalho me proponho a tecer algumas considerações sobre os determinantes de gênero na dinâmica das relações sociais a partir de uma perspectiva feminista. Entendo, porém, que, nas sociedades contemporâneas, capitalismo, sexismo, racismo, etarismo, e lesbo/homofobia, dentre outras matrizes de opressão, não agem independentemente. Estão imbricadas ou em "simbiose", constituindo-se como matrizes de opressão que se entrelaçam e se reforçam, forjando sistemas de estratificação e opressão interseccionados. Da mesma forma, gênero, raça e classe e demais marcadores de diferença e elementos constitutivos das relações sociais não atuam separadamente. Esses elementos se intersectam e recortam uns aos outros, modificando, mutuamente, uns aos outros. Isso implica dizer que as respectivas categorias de gênero, raça, classe e outras categorias sociais similares não são categorias autônomas. Daí porque precisamos pensar em instrumentos conceituais que nos permitam identificar e analisar como estruturas de privilégio e opressão se intercruzam em diferentes níveis e se manifestam na vida cotidiana das mulheres e na construção de suas identidades. Nesse intuito, baseio-me aqui na noção de "caleidoscópios de gênero" que, acredito, nos permite melhor dar conta desses processos.
\end{abstract}

Palavras-chave: Gênero e interseccionalidades. Gênero na dinâmica das Relações Sociais. Caleidoscópios de gênero.

1 Uma primeira versão deste trabalho foi apresentada à Mesa: “Feminismo e Negritude:

Desafios Contemporâneos", durante o "I Seminário Internacional, Gênero, Raça, Classe e Identidade Social no Brasil e na França", promovido pelo NEIM/UFBA, Salvador, Bahia, 5-8 de agosto de 2009. O trabalho é um desdobramento da disciplina "Dinâmica das Relações Sociais de Gênero, Raça e Classe" que venho oferecendo, por mais de uma década, no PPGCISO da UFBA, e, mais recentemente, no PPG-NEIM. Beneficio-me, portanto, da contribuição das várias alunas que cursaram essa disciplina, a quem sou muito agradecida.

2 Docente dos Programas de Pós-Graduação em Estudos Interdisciplinares sobre Mulheres, Gênero e Feminismo - PPG-NEIM e de Antropologia - PPGA, da Universidade Federal da Bahia e Pesquisadora do NEIM-Núcleo de Estudos Interdisciplinares sobre a Mulher E-mail: cecisard@ufba.br 


\title{
Gender Kaleidoscopes: GeNDER ANd INTERSECTIONALITIES IN THE \\ DYNAMICS OF SOCIAL RELATIONS
}

\begin{abstract}
In this work I propose to weave some considerations on gender determinants in the social relations dynamics, from a feminist perspective. However, I understand that in contemporary societies capitalism, sexism, racism, ageism, and lesbo/homophobia (among other oppression matrices) do no act separately. They are imbricated or in 'symbiosis' as oppression matrices that interlace and are mutually reinforcing and forging systems of stratification and oppression that intersect each other. In the same manner, gender, race, class and other difference markers and elements that constitute social relations do not act independently. These elements intersect and mutually modify each other, such that the respective categories of gender, race, class, and so on, are not autonomous. As such, we need to devise conceptual tools that allow us to identify and analyze how structures of privilege and oppression intersect each other at different levels in the daily women lives and in the construction of their identities. For this purpose, I work here with the notion of "gender kaleidoscopes", which I believe can offer us a better basis to understand these processes.
\end{abstract}

Keywords: Gender and intersectionalities. Gender in the social relations dynamics. Gender kaleidoscopes.

\section{INTRODUÇão}

Dor muito tempo, predominou no pensamento social uma noção 1 estática de classes sociais, retratando-as como coletividades homogêneas, determinadas apenas pelo lugar ocupado no processo de produção. Nessa perspectiva, membros de uma determinada classe partilhariam dos mesmos interesses inerentes às contradições de classe, o que lhes imprimiria, automaticamente, uma dada identidade, tomada então como fator primordial na constituição de sujeitos políticos. Desde meados dos anos 1960, contudo, essa concepção de classe tem sofrido severas críticas e reformulações. De um lado, considerações quanto à importância do agency na construção da consciência de classe, no sentido de que a consciência de classe se forja na luta de 
classes (THOMPSON, 1980) e, de outro, a emergência de movimentos sociais fundamentados em outras bases - movimento feminista, movimento negro, movimento gay, dentre outros - tem revelado as limitações "[...] dos grandes esquemas explicativos e sua ênfase nas determinações macroestruturais como única fonte explicativa das lutas sociais" (KOWARICK, 1988, p.6). Mais especificamente, a entrada de mulheres, negros, gays, lésbicas, aposentados e moradores das periferias das grandes cidades no cenário político, reclamando espaço e o devido reconhecimento de suas especificidades e direitos, não apenas mostrou a relevância de outros fatores constituintes de sujeitos políticos, como também colocou em xeque a imagem de classes sociais como coletividades homogêneas, revelando, ao invés, uma imagem de classe multifacetada e com clivagens internas (PAOLI, 1987; PAOLI \& SADER, 1986). Não é, pois, ao acaso que outras categorias ou marcadores sociais de diferenciação - e dentre eles, em especial, gênero e raça - passaram a ser vistos como igualmente importantes aos determinantes de classe no processo de mobilização política.

De fato, hoje se reconhece que, por operarem também como matrizes preponderantes de hierarquização, desigualdade social e subordinação na grande maioria das sociedades contemporâneas, racismo e sexismo, ao lado do capitalismo, produzem diferenças relevantes em termos de gênero e raça na experiência de classe - $o$ que, não raro, pode se traduzir em divergências de interesses entre membros de um mesmo segmento social. Da mesma forma, observase que recortes de classe e raça reconfiguram as vivências de gênero e estas, junto às de classe, recortam a maneira em que homens e mulheres vivenciam o racismo e suas implicações, produzindo experiências muito distintas. Além disso, como vem se reconhecendo mais recentemente, etarismo, lesbo/trans/ homofobia e o capacitismo, que discrimina pessoas com deficiências, dentre outros marcadores de diferenciação, também se mostram como elementos relevantes 
na reprodução de desigualdades sociais e, assim, na construção de novos sujeitos políticos. Tudo isso torna premente a necessidade de se pensar, mais a fundo, a dinâmica das relações sociais nas sociedades contemporâneas.

Com esse objetivo maior em mente, me proponho, neste trabalho, a tecer algumas considerações sobre os determinantes de gênero na dinâmica das relações sociais a partir de uma perspectiva feminista. Entendo, porém, que, nas sociedades contemporâneas, capitalismo, sexismo, racismo, etarismo, e lesbo/homofobia, dentre outras matrizes de opressão, não agem independentemente. Ao contrário, estão por assim dizer, imbricadas, ou em "simbiose" (SAFFIOTI, 1992), constituindo-se como matrizes de opressão que se entrelaçam e se reforçam (COLLINS, 1989), forjando sistemas de estratificação e opressão interseccionados (CRENSHAW, 1991). Da mesma forma, gênero, raça e classe e demais elementos constitutivos das relações sociais (SCOTT, 1988) não atuam separadamente. Esses elementos se intersectam e recortam uns aos outros, modificando, mutuamente, uns aos outros. Isso implica dizer que as respectivas categorias de gênero, raça, classe e outras categorias sociais similares não são categorias autônomas. Daí porque, ainda que privilegiando o enfoque de gênero, reconheço que nem tudo é "uma questão de gênero" e, assim, que no contexto da vida social, "gênero" não é vivenciado separadamente. Precisamos, pois, pensar em instrumentos conceituais que nos permitam identificar e analisar como estruturas de privilégio e opressão se intercruzam em diferentes níveis e se manifestam na vida cotidiana das mulheres e na construção de suas identidades.

Nesse intuito, baseio-me aqui nas considerações de feministas negras americanas, notadamente Kimberlé Crenshaw (1991), com sua relevante contribuição sobre as "interseccionalidades" - em particular, sua metáfora das avenidas que se cruzam e entrecruzam -, bem como em Patricia Hill Collins (2000) e sua conceituação de "opressões 
que se entrelaçam", noção para a qual também contribuiu Heleieth Saffioti $(1992 ; 1996)$ falando da "simbiose do patriarcado, racismo e capitalismo". Acredito, porém, que a noção de "caleidoscópio de gênero", proposta por Joan Spade e Catherine Valentine (2008), nos permite dar conta melhor desses processos.

Conforme delineado por essas autoras, um caleidoscópio é um tubo contendo espelhos e prismas que se combinam e recombinam para produzir imagens e desenhos diferentes, a depender da movimentação do tubo. Quando olhamos pelo visor do caleidoscópio, a luz dos espelhos se reflete nos prismas por meio de células contendo pedaços de vidro, conchas e elementos semelhantes, o que cria diferentes 'mosaicos', ou padrões de desenho e cores, a cada movimento do tubo (SPADE \& VALENTINE, 2008, p.xiv). Se tomarmos as categorias gênero, raça, classe, etnia, idade, etc., como "prismas sociais" e os espelhos como o contexto em que se refletem no tempo e espaço sociais, a metáfora do caleidoscópio nos permite apreender a dinâmica das relações sociais na medida em que o "prisma de gênero" interage com os demais "prismas sociais" (de raça, etnia, idade, sexualidade, classe social, etc.), produzindo "mosaicos" distintos, ou complexos padrões de identidades e relações (SPADE \& VALENTINE, 2008, p.xiii), que são sempre historicamente específicos. É o entrecortar desses 'prismas', em diferentes contextos, que define as nossas "[...] experiências de gênero através do espectro das nossas vidas gendradas" (SPADE \& VALENTINE, 2008, p. xi).

No que se segue, explicitarei mais a fundo como esses processos se desenrolam. Ressalto, porém, que procuro trabalhar os conceitos em questão dentro da perspectiva da dinâmica das relações sociais, em uma dimensão histórica, propondo que é nesse contexto que as "opressões que se entrelaçam" dão margem a intersecções específicas dos "prismas" de gênero, raça, classe e outras categorias semelhantes, configurando, assim, mosaicos distintos, tal como se observa num 
caleidoscópio. Por isso mesmo defendo que a forma que essas relações tomam em um determinado contexto é sempre histórica, social, e culturalmente específica: não pode nunca ser deduzida de como se expressam em outros contextos. Isso implica sempre na necessidade de análises substantivas, baseadas na investigação empírica.

Para levar adiante minha proposta, creio ser fundamental retomarmos o fio da meada das discussões atuais sobre "interseccionalidades", o que nos leva a revisitar algumas das questões levantadas nos debates travados entre Feministas Marxistas, Socialistas e Radicais na década de 1970, conhecidos por "Debate sobre Sexo e Classe". Volto-me, a seguir, para o desafio posto pelas feministas não brancas, as feministas negras norte-americanas, no particular, bem como por feministas que apontam para a necessidade de uma perspectiva geracional (BRITTO DA MOTTA, 1999) e pela crítica à heteronormatividade (BUTLER, 1990). Elas têm levado a discussão para um outro plano - o das interseccionalidades, das "opressões que se entrelaçam" e dos mosaicos que se desenham nos caleidoscópios de gênero na dinâmica das relações sociais.

Antes de avançarmos nessas considerações, creio ser importante ressaltar que, ao falar de racismo e sexismo no que se segue, estarei me referindo a sistemas de dominação que se baseiam em doutrinas sobre a superioridade de determinados grupos ou categorias sociais em relação a outros. No caso do sexismo, tais hierarquias se constroem a partir da diferenciação entre os sexos, ao passo que, no tocante ao racismo, tomam-se outras diferenças físicas - cor, tipo de cabelo, tipo de nariz, etc. - para se construir desigualdades sociais (SARDENBERG, 2011). Nas sociedades capitalistas contemporâneas, o sexismo está estruturado em uma ordem de gênero patriarcal, que podemos identificar apenas como ' patriarcado', resultado de processos históricos que se entremearam ao racismo (LERNER, 1986; SAFFIOTI, 1996; 2008; STOLCKE, 2006). 
É preciso destacar, porém, que enquanto o conceito de 'sexo' ainda tem estatuto científico, 'raça' não é considerada uma categoria 'científica'; já se descartou há tempo a noção de que existem raças distintas dentre a espécie humana (SARDENBERG, 2011). Assim mesmo, o conceito de 'raça' continua a ter relevância sociológica, vez que processos de 'racialização', classificação e inferiorização de determinados grupos com base nas suas características físicas permanecem em curso. Nesse caso, raça constitui-se como uma categoria classificatória, uma categoria dita 'nativa', ou melhor, como “[...] discursos sobre as origens de um grupo, que usam termos que remetem à transmissão de traços fisionômicos, qualidades morais, intelectuais, psicológicas, etc., pelo sangue (conceito fundamental para entender raças e certas essências)" (GUIMARÃES, 2003, p.94).

Já o conceito de 'etnia' não se refere, necessariamente, a características físicas, e sim a "discursos sobre as origens e história de um grupo", tendo como referenciais básicos lugares geográficos de origem e crença num parentesco real ou fictício (BARROS, 2005; GUIMARÃES, 2003; SARDENBERG, 2011). Não cabe, pois, substituir o termo 'raça' por 'etnia'; esses termos não são intercambiáveis, já que se referem a fenômenos distintos. Ademais, "[...] apesar de não ter validade como conceito científico, raça ainda tem validade social, pois é a ideia que fundamenta o racismo existente em nossa sociedade" (BARROS, 2005, p.36).

\section{O DEBATE SOBRE SEXO E CLASSE}

Durante toda a década de 1970, travou-se um esquentado debate entre marxistas, feministas, marxistas-feministas e feministassocialistas (e outras mais que não cabiam nesses rótulos), que se tornou conhecido como "debate sobre sexo e classe". Na verdade, esse debate começara ainda nos anos 1960, com a retomada dos 
movimentos feministas e a consequente reabertura da discussão com o Marxismo, iniciada ainda no século XIX, com Frederick Engels. Inspirado nas copiosas anotações de Karl Marx sobre "sociedades antigas" $^{3}$ e sua própria leitura do livro de Lewis Henry Morgan (1985), Ancient Society, e outros autores ditos 'evolucionistas', Engels escreveu A Origem da Família, da Propriedade Privada e do Estado, expressando, no Prefácio dessa consagrada obra, sua admiração (e a de Marx) pelo livro de Morgan, a quem atribuiu ter identificado "[...] na América a abordagem materialista da história descoberta por Marx há quarenta anos [...]" (ENGELS, 1972, p.71).

Tanto Morgan quanto Engels incluíram nessas citadas obras longas passagens sobre a "questão da mulher" e não por acaso: os movimentos feministas estavam em grande evidência na Europa como nos Estados Unidos no período em questão. Por certo, Morgan e Engels não foram os únicos a responderem às questões levantadas pelos movimentos feministas. De um modo geral, todos os evolucionistas o fizeram, ainda que de forma indireta, como bem observou a historiadora Elizabeth Fee (1974) ${ }^{4}$. Todavia, Morgan, ao contrário de seus contemporâneos, previa igualdade entre os sexos no futuro. Ele argumentou que a inferiorização da mulher era produto da história (e não algo 'natural' ao seu sexo), afirmando que esse processo estaria atrelado à (suposta) transição do matriarcado para o patriarcado, resultante do surgimento da "ideia de propriedade privada" dos meios de subsistência. Morgan ofereceu um complexo esquema de evolução social baseado em vários estágios, ou "períodos étnicos", caracterizados pela articulação de formas específicas de organização

\footnotetext{
3 Essas anotações de Marx foram reunidas por Lawrence Krader e publicadas sob o título The Ethnological Notebooks of Karl Marx (MARX; KRADER, 1972).

4 Em artigo que se volta para a "Política Sexual da Sócio-Antropologia Vitoriana", Fee (1974) discute as obras de Henry Maine, Johan J. Bachofen, John McLennan, John Lubbock, Herbert Spencer e Morgan e Engels, mostrando como, à exceção desses últimos, os evolucionistas responderam ao feminismo da época colocando as mulheres em seu lugar - de subalternidade.
} 
das "artes de subsistência", da família, do tipo de propriedade e de formas de governo, que se estenderiam da 'selvageria' a 'civilização'. Engels endossou essa perspectiva, acreditando que essa noção de "períodos étnicos" se assemelhava à noção de modo de produção de Marx, razão pela qual se inspirou nessa obra para escrever $A$ origem da família .

Por certo, A Origem da Família, da Propriedade Privada e do Estado é muito mais do que uma análise da situação da mulher; na verdade, trata-se de um contraste entre sociedades de classe e sociedades igualitárias (LEACOCK, 1972). Nos limites deste trabalho, contudo, interessa-nos apenas observar que, seguindo as considerações de Morgan, Engels argumentou ter o surgimento da propriedade privada minado a ordem tribal, tornando a família uma unidade econômica, o que em tempo deu margem ao surgimento de desigualdades no acesso aos meios de produção e, assim, às classes sociais e, por fim, à exploração da mulher na família.

No capítulo sobre "Família", Engels procurou mostrar como as mulheres foram transformadas de seres livres e membros produtivos da sociedade em esposas dependentes ${ }^{6}$. Para ele, na medida em que a origem da opressão da mulher estava supostamente ligada ao surgimento da propriedade privada, só com o fim da sociedade de classes é que as mulheres poderiam se emancipar. Em especial, Engels ressaltou a importância da participação da mulher no mercado de trabalho nesse processo, por acreditar que isso lhe concederia maior independência econômica e, portanto, maior autonomia. Salientou também que as mulheres proletárias supostamente gozariam de maior liberdade do que as burguesas, por não desfrutarem da propriedade de meios de produção.

\footnotetext{
$5 \quad$ Veja-se o livro Marxism and Primitive Society no qual Emmanuel Terray (1972) faz uma leitura marxista-estruturalista de Morgan.

6 Veja-se, também, as considerações de Karen Sacks (1979) sobre essas questões.
} 
Apesar de ser uma obra relevante para se pensar as possíveis bases materiais da subordinação das mulheres na sociedade, os argumentos de Engels têm sido bastante criticados por antropólogos por seus furos etnográficos ${ }^{7}$, sendo também foco da crítica feminista. Dentre alguns dos pontos levantados por feministas, destaca-se o fato de Engels, assim como Marx, não ter problematizado a divisão sexual do trabalho, entendendo-a como algo 'natural'. Engels também não discutiu a questão do trabalho doméstico desenvolvido por mulheres na família, deixando em aberto seu significado e função nas sociedades capitalistas. E não ofereceu meios para darmos conta das assimetrias de gênero em sociedades tribais supostamente igualitárias (sem propriedade privada dos meios de produção), tampouco para se explicar a persistência da situação de subalternidade das mulheres nas sociedades socialistas. Sem esquecer que, como bem observou Emma Goldman (1911) em seu ensaio sobre "O Tráfico em Mulheres", escrito há mais de um século, a vida das mulheres trabalhadoras, nas sweatshops, estava longe de ser 'emancipatória'.

Sem dúvida, grande parte dessas limitações nos argumentos de Engels se deve à sua tentativa de atrelar a questão da subordinação das mulheres na sociedade a um aspecto da 'base econômica' e, em especial, ao surgimento das sociedades de classe, quando hoje verificamos se tratar de um fenômeno muito mais complexo. Notese que, em O Segundo Sexo, Simone de Beauvoir (2009) levantou algumas dessas críticas ao trabalho de Engels, reconhecendo, porém, sua importância como tentativa de busca das causas materiais do referido fenômeno. Mas foi só a partir da emergência dos movimentos feministas contemporâneos na década de 1960, que as limitações do esquema de Engels e as contribuições de Marx foram alvo de maior escrutínio, inclusive por parte de feministas socialistas, a exemplo de Juliet Mitchell (1967) e Sheila Rowbotham (2009). Várias outras

Sobre essa questão, veja-se, por exemplo, o ensaio de Maurice Godelier (1977). 
feministas, tais como, Shulamith Firestone (1976), Kate Millett (1975) e Gayle Rubin (1975), também dialogaram (ainda que nem sempre abertamente) com as colocações de Marx e Engels, mas, na sua maioria, na tentativa de oferecer uma teoria feminista das 'origens' da subordinação feminina na sociedade, hoje na mira da crítica pósmoderna.

Paralelamente a esse esforço de diálogo, outro debate se iniciaria entre marxistas e feministas em torno da dinâmica de sexo e classe. De um lado, feministas (radicais) fazendo a crítica ao Marxismo, argumentaram que as análises marxistas eram cegas para sexo/gênero e, de outro, marxistas fazendo a crítica ao feminismo, ressaltaram que as feministas eram cegas para classe, não levando a história em consideração. Seguiram-se, assim, as várias tentativas de 'casar' marxismo e feminismo, tentativas essas geralmente vistas como malsucedidas (BURNHAM \& LOUIE, 1985).

Não por acaso, Heidi Hartmann (1979) nos falou do "casamento infeliz" entre marxismo e feminismo, observando o quanto essa relação havia sido desigual ${ }^{8}$. De acordo com Hartmann (1979), muito embora precisássemos tanto do método marxista quanto da análise feminista para melhor entendermos as sociedades capitalistas contemporâneas, principalmente, a situação das mulheres nessas sociedades, o feminismo havia sido insistentemente subordinado. Para ela, o marxismo inseriu as lutas feministas (lutas específicas) nas lutas "gerais" contra o capital, absorvendo a análise feminista na luta de classe. Ademais, as categorias de análise marxistas se mostraram "cegas para o sexo", portanto, não poderiam analisar a reprodução do sexismo. Em contrapartida, as análises feministas ditas 'radicais' não levaram a "história" em consideração, tampouco se preocuparam com

8 L. Burnham e M. Louie (1985) falam de um “casamento impossível” entre marxismo e feminismo, porque, entre outros problemas, partem de princípios diferentes - epistemologias diferentes. Tentativas de casamento caem em dualismos analíticos, que não explicam nada. $S$. Himmelweit (1984) vai argumentar que esse dualismo de sexo e classe é "real". 
os recortes de classe. Hartmann (1979) ressaltou que o desenvolvimento capitalista cria postos para uma hierarquia de trabalhadores, mas as categorias marxistas não especificavam quem iria ocupá-los. Disse ela: "São as hierarquias de gênero e raça que determinam quem assumirá esses postos" (HARTMANN, 1979, p.13). Tratava-se, pois, de uma 'parceria' entre patriarcado e capitalismo - e, poderíamos acrescentar, racismo - que precisaria ser mais bem analisada. Daí porque, na perspectiva dessa autora, seria preciso construir uma análise que combinasse patriarcado e capitalismo, num casamento mais "feliz" entre marxismo e feminismo.

Seguindo essa linha de pensamento, Zilah Eisenstein (1980) procurou desenvolver uma "teoria do patriarcado capitalista", argumentando a favor de um feminismo socialista para combatê-lo de forma mais eficaz. Eisenstein (1980) argumentou que a síntese do feminismo radical com a análise marxista seria um passo fundamental nesse sentido, mas tal síntese não poderia significar apenas a soma de uma teoria de poder com a outra, seria necessário inter-relaciona-las por meio da análise da divisão sexual do trabalho. Ela definiu o 'patriarcado capitalista' como "[...] a relação que reforça mutuamente a estrutura de classe capitalista e a estrutura sexual hierárquica do patriarcado" (EISENSTEIN,1980, p.15), ressaltando que essas estruturas seriam interdependentes, portanto, tanto a análise de classe quanto a de sexo seriam passos essenciais para a erradicação da estrutura de opressão vigente nas sociedades capitalistas contemporâneas. Argumentou, ainda, que embora o patriarcado tivesse historicamente precedido à emergência do capitalismo e tendesse a continuar nas sociedades póscapitalistas, precisaríamos entender como se estabeleceu e se mantém essa relação entre os dois sistemas de opressão para provocarmos mudanças radicais.

Segundo essa autora, o desenvolvimento do patriarcado capitalista poderia ser datado em meados do século XVIII, na 
Inglaterra, e início do século XIX, nos Estados Unidos, época em que se desenvolveu o capitalismo industrial. Seria, portanto, resultado de condições históricas específicas que levaram a um processo de rompimento das "[...] dicotomias de sexo e classe, de esfera pública e privada, de trabalho doméstico e trabalho para o mercado, família e economia, pessoal e político e entre condições materiais e ideológicas" (EISENSTEIN, 1980, p.23).

Ressalte-se aqui que um dos eixos do debate em questão se voltou, precisamente, para a persistência da divisão sexual do trabalho no capitalismo: seria esse fenômeno apenas uma sobrevivência de ideias patriarcais, ou seja, apenas um fator histórico, ou, ao contrário, estaria de fato atrelado, imbricado, ou mesmo determinado pela dinâmica do modo de produção capitalista? Na perspectiva de Eisenstein, tal relação se deu fortuitamente a partir de processos históricos. Já Pat e Hugh Armstrong (1983) defenderam ser a divisão sexual do trabalho essencial à própria dinâmica do modo de produção capitalista e não apenas resultante de condições históricas. Partindo das discussões sobre o trabalho doméstico no capitalismo, esses autores afirmaram que a divisão sexual do trabalho é essencial a este modo de produção, no nível mais alto de abstração. Em outras palavras, para os Armstrong: se a divisão sexual do trabalho não existisse antes, teria que ser criada pelo capitalismo, caso contrário esse modo de produção não poderia se reproduzir.

Tal argumento se fundamentou na noção de que o capitalismo é baseado no princípio do "trabalho livre", portanto, a reprodução da força de trabalho teria que acontecer em alguma unidade fora da esfera de produção de bens e serviços, no caso, na família. E, uma vez que são as mulheres que engravidam e têm os filhos, isso impõe uma divisão sexual do trabalho, implicando também a separação do lar do local de trabalho e a segregação e subordinação da mulher na família. Assim, defendem a premissa de que a separação do lar e do local de 
trabalho, supostamente necessária à produção 'livre' da mercadoria 'força de trabalho', implicaria na segregação da mulher. O que, por sua vez, tornaria a divisão sexual do trabalho fator essencial à dinâmica do modo de produção capitalista, estabelecendo-se, portanto, uma relação lógica, sine qua non, entre um e o outro fenômeno. Na perspectiva dos Armstrong (1980), tal qual apregoado por Auguste Bebel (1977) e outros pensadores marxistas, só com o fim do capitalismo se poderia ter uma verdadeira emancipação das mulheres.

Observe-se que os Armstrong (1980) não usaram o termo 'gênero'; falaram de 'sexo' e classe por acreditarem que a articulação de sexo e classe se dá no 'mais alto nível de abstração' no pensamento marxista, ou seja, no nível do 'modo de produção'. Mas, não custa lembrar que embora o termo 'gênero' já circulasse nas reflexões feministas desde o início dos anos 1970 - por exemplo, ele é definido como central para os estudos feministas no livro Sex, Gender and Society, publicado pela socióloga Ann Oakley (1972), nesse mesmo período. Será somente a partir da década de 1980 que esse termo passará a ser considerado objeto maior das teorizações feministas (SARDENBERG, 2014a).

De fato, no espaço de uma década - precisamente quando se debatia 'sexo e classe'-, caminhou-se da "questão da mulher" aos "estudos sobre mulheres", registrando-se nesse processo a grande diversidade do 'ser mulher' (e do ser homem) no tempo e no espaço histórico-geográficos e sociais. Ao mesmo tempo, verificou-se a existência de uma tendência universal a se tomar as diferenças percebidas/construídas entre os sexos como base para o estabelecimento de uma divisão sexual do trabalho e uma hierarquia entre os sexos (quase sempre em favor do masculino), construções, divisões e hierarquias essas que em muito se distanciam de qualquer determinação biológica. Chegou-se, assim, à construção do conceito de gênero, instrumento de análise que pretendeu dar conta desses 
fenômenos, ou seja, da construção social das diferenças e desigualdades entre os sexos. Definido em termos gerais como "elemento constitutivo das relações sociais baseado nas diferenças percebidas entre os sexos" e como uma "forma primeira de significar as relações de poder", na concepção da historiadora Joan Scott (1988), gênero tornou-se o objeto maior dos estudos feministas.

Baseando-se, pois, nessa perspectiva, Michelle Barrett (1980) e Patricia Connelly (1986) introduzem o conceito de gênero no debate, deslocando as discussões do nível do modo de produção para o da formação social e econômica. Segundo observou Patricia Connelly (1986), o sistema capitalista pode ser analisado em diferentes níveis de sua organização. Primeiro, em um nível mais abstrato que se refere à dinâmica do sistema e ao que é absolutamente essencial para o surgimento e desenvolvimento do capitalismo. Para ela, é bastante questionável se nesse nível a divisão sexual do trabalho é de fato essencial. Já em um segundo nível de análise, tem-se a formação social capitalista, que se refere a um nível mais concreto e historicamente específico. É nesse nível que se torna importante pensar 'gênero', ou melhor, investigar como as relações sociais de produção e as relações de gênero combinam ou contrastam em classes diferentes e em períodos históricos diferentes, ou seja, em formações sociais distintas. Isso porque as relações de gênero não podem ser lidas diretamente das relações de produção, já que há um fator histórico operando, há intervenções culturais. Sem dúvida, algumas tendências podem ser observadas em todas as sociedades capitalistas em relação à divisão sexual do trabalho, mas há variações importantes segundo as características da formação social em consideração, vez que o desenvolvimento do capitalismo se dá de maneira diferenciada em formações sociais distintas.

Tal como Patricia Connelly, Michelle Barrett (1980) também insistiu não ser a divisão do trabalho com base no gênero um elemento 
necessário à lógica do modo de produção capitalista. Ela argumentou que as divisões de gênero precedem o surgimento do capitalismo, mas, no seu desenvolvimento, o capitalismo adotou, adaptou e faz uso dessa divisão entre homens e mulheres, de sorte que a divisão sexual do trabalho e a subordinação da mulher se imbricaram a tal ponto na dinâmica do capital, que se tornaram elementos cruciais, mesmo não sendo essenciais. Historicamente, essa imbricação se manifestou, em particular, no sistema casa-família, em que o 'salário família' permitiria, em tese, a reprodução da divisão sexual do trabalho, mantendo as mulheres na domesticidade.

De fato, conforme ressaltei em trabalho anterior (SARDENBERG, 2001), embora saibamos que o capitalismo, enquanto modo de produção, não tenha criado o modelo de família em questão, tampouco possa ser caracterizado como "sexista", é certo que, historicamente, o capital tem se servido das construções e divisões de gênero nele implícitas, explorando o trabalho da mulher de uma dupla maneira:

De um lado, baseando-se na noção de que a mulher é a parte dependente do casal, o capital tem se beneficiado da exploração direta do trabalho feminino na produção, pagando-lhe salários inferiores ao trabalho masculino, o que contribui para a desvalorização da força de trabalho como um todo. De outro lado, o capital se serve da exploração indireta do trabalho feminino, beneficiando-se das atividades desempenhadas "de graça" pela mulher no âmbito doméstico para os membros da família. Pode assim pagar salários menores ao trabalhador, já que o trabalho da mulher/mãe/esposa atende (pelo menos em parte) às necessidades de reposição física do trabalhador e, em última instância, à reprodução da mercadoria "força de trabalho" (SARDENBERG, 2001, p.20). 
É possível assim afirmarmos, junto com Heleieth Saffioti (1992, p.36), que "[...] as relações de classe estão presentes na reprodução, assim como as relações de gênero penetram na produção". Cabe, pois, procurarmos "[...] detectar a presença das diferenças-semelhanças de gênero nas relações de produção, assim como as diferençassemelhanças de classe nas relações de gênero", já que "estes dois tipos de relações são absolutamente recorrentes, impregnando todo o tecido social" (SAFFIOTI, 1992, p.18-19). Poderíamos acrescentar que, assim articuladas, as relações de gênero e de classe têm produzido não apenas ganhos econômicos, mas também políticos para o capital, na medida em que tal articulação pode gerar conflitos de interesse entre homens e mulheres no interior das classes trabalhadoras.

Estudos sobre classes trabalhadoras têm constatado que, de fato, gênero e classe se articulam de sorte a produzir vivências e experiências de classe bastante distintas para homens e mulheres. $\mathrm{Na}$ verdade, as dimensões de gênero nas vivências de classe parecem se manifestar entre famílias das classes trabalhadoras desde a mais tenra idade, como bem nos apontou Zahidê Machado Neto (1984) em um estudo sobre meninos e meninas em bairros pobres de Salvador. Martha A. Traverso-Yépez e Verônica de Souza Pinheiro (2005) nos mostraram que essas dimensões se acentuam ainda mais na adolescência, conforme estudo realizado com jovens de ambos os sexos na periferia de Natal, Rio Grande do Norte.

Não causa surpresa, pois, o fato de que os recortes de gênero se façam sentir nitidamente na experiência fabril, a exemplo dos contrastes entre operários e operárias, destacados por Elizabeth SouzaLobo e Vera Soares (1991) no contexto de uma pesquisa desenvolvida em fábricas da região do $\mathrm{ABC}$ em São Paulo.

Também eu, em meus estudos sobre o antigo operariado baiano, pude constatar os inegáveis contrastes entre a experiência de operárias e operários, seja no espaço fabril quanto do bairro 
(SARDENBERG, 1998). Isso se reflete em suas memórias, conforme ressaltei em artigo anterior:

[, Ela se mostra diferente para diferentes gerações de trabalhadores e, no particular, recortada em termos de gênero, refletindo a experiência operária distinta de homens e mulheres na fábrica, no espaço do bairro e, principalmente, nos movimentos grevistas, instância em que as mulheres tiveram apenas uma participação marginal. Assim, enquanto os homens guardam uma memória 'heroica' dessas lutas, a memória social das mulheres, nesse tocante, revela-se fragmentada, contraditória e, não raro, negativa ou mesmo 'anti-heroica'. Para elas, o que parece ter ficado registrado são imagens da violência perpetrada contra a comunidade durante as greves, principalmente, instâncias de vitimação de mulheres. Isso se coaduna às lembranças da vida na fábrica; as mulheres, muito mais do que os homens, têm vivos na memória detalhes de acidentes verificados no trabalho, das condições bastante insalubres sob as quais se viam obrigadas a trabalhar e de atos despóticos por parte de supervisores contra os seus subordinados. Surpreendentemente, são, contudo, as mulheres que recordam, com maior nostalgia e saudades, não apenas a vida no bairro enquanto vila operária, como também seu trabalho na fábrica, idealizando esse passado operário como a melhor época de suas vidas (SARDENBERG, 1998, p.149-150).

Da mesma forma, recortes de classe se impõem nas vivências de gênero, construindo clivagens nas experiências de mulheres de classes distintas e trazendo as contradições de classe para o plano das convivências. Esse processo foi observado por Alda Britto da Motta (1986) em estudo sobre as relações entre patroas e empregadas em Salvador, uma relação por ela identificada como a "relação impossível". Relação semelhante constatou Maria Odila Leite da Silva Dias (1984) em seu estudo sobre "senhoras e ganhadeiras" na São Paulo do século 
XVIII, que demonstrou como as primeiras (as 'senhoras') viviam a partir da exploração das outras (as 'ganhadeiras'), suas escravas negras. Mas aqui entramos já em um terceiro determinante - raça que abordarei a seguir.

\section{RAÇA, CLASSE E GÊNERo: A CONTRIbUição dAS FEMINISTAS NEGRAS}

Em 1851, durante a "Convenção de Mulheres" realizada na cidade de Akron, Ohio, nos Estados Unidos, a negra liberta conhecida por Sojourner Truth respondeu a argumentos de que as mulheres eram muito frágeis e dependentes para terem direito ao voto, ressaltando a experiência distinta das mulheres negras, assim se expressando:

Aquele homem ali diz que as mulheres precisam ser ajudadas para subir em carruagens, carregadas para passar sobre valas e ter sempre os melhores lugares. Ora, ninguém me ajuda a subir em carruagens, ou a pular poças de lama, ou me oferece qualquer lugar! E não sou eu mulher? Olhe para mim! Olhe o meu braço! Eu tenho arado, plantado e enchido os celeiros e nenhum homem ganhou de mim. E não sou eu mulher? Eu podia trabalhar e comer tanto quanto os homens - quando conseguia comida - e aguentar o chicote também! E não sou eu mulher? Eu dei a luz a quinze filhos e vi quase todos serem vendidos como escravos, mas quando chorei minha dor de mãe, ninguém a não ser Jesus me ouviu! E não sou eu mulher? (TRUTH, 1851, tradução nossa).

Em seu argumento, Sojourner Truth expressou a especificidade de sua condição marcada pelos determinantes de gênero, raça e classe, mas vivenciados simultaneamente, um definindo os outros e viceversa, numa situação de escravidão. Ela não separou uma situação de opressão (de gênero, raça e classe) da outra, experimentandoas na sua simultaneidade - aliás, como acontece com todas nós em 
nosso cotidiano. Contudo, em termos teóricos, só mais recentemente começamos a construir os instrumentos de análise para dar conta dessa complexidade.

Passos nesse sentido foram inicialmente traçados por feministas negras norte-americanas, ao tempo em que se desenrolava o debate sobre sexo e classe. Insatisfeitas, de um lado, com o movimento negro e as reflexões sobre racismo que não consideravam a situação de gênero específica das mulheres negras e, de outro, com os movimentos e teorizações feministas que pouca atenção dedicavam aos determinantes de classe e raça nessas vivências de mulheres negras, feministas negras norte-americanas passaram a refletir sobre sua condição distinta. A partir da articulação da National Black Feminist Organization, em 1973, surgiram diferentes grupos de feministas negras, dentre eles, o Combahee River Collective, criado em 1974 em Boston, como um grupo de conscientização e reflexão, do qual participaram bell hooks e Audrey Lorde, dentre outras. Em 1977, esse grupo se reorganizou enquanto grupo de estudo, lançando um documento no qual se identificava como um grupo de feministas negras e socialistas, traçando seu posicionamento político - e teórico nos seguintes termos:

A afirmativa mais geral sobre a nossa política no presente é estarmos ativamente compromissadas para lutar contra a opressão racial, sexual, heterossexual e de classe, vendo como nossa tarefa principal o desenvolvimento de uma análise e prática integradas baseadas no fato de que os principais sistemas de opressão estão imbricados. A síntese dessas opressões constrói nossas condições de vida. Como mulheres negras, vemos o feminismo negro como o movimento político mais lógico para combater as múltiplas e simultâneas opressões que todas as mulheres negras enfrentam (COMBAHEE RIVER COLLECTIVE, 1981, p.210, tradução nossa). 
Nesse documento, as feministas do Combahee River Collective afirmavam a simultaneidade da opressão sexual e de raça e classe em suas vidas, falando da dificuldade em separar essas múltiplas e simultâneas opressões, pois, ao contrário do que se propagava na época, elas não se sobrepõem nem se somam, mas se recortam e imbricam, umas nas outras. Conforme ressaltaram mais adiante, no mesmo documento:

Acreditamos que a política sexual no patriarcado é tão difusiva na vida das mulheres negras assim como as políticas de classe e de raça. Temos dificuldade em separar a opressão de raça, da de classe e da sexual, porque em nossas vidas elas são vivenciadas simultaneamente. E sabemos que existe algo como uma opressão racialsexual que não é somente racial nem somente sexual, por exemplo, a história do estupro de mulheres negras por homens brancos como um instrumento de repressão política (COMBAHEE RIVER COLLECTIVE, 1981, p.213, tradução nossa).

Um dos importantes desdobramentos desse posicionamento foi a publicação da coletânea, But Some of Us Are Brave: All the Women Are White, All the Blacks Are Men: Black Women's Studies, organizada por Gloria T. Hull, Patricia Bell Scott e Barbara Smith (1982). Reunindo artigos de feministas negras trabalhando em diferentes campos de estudo, essa coletânea argumentou em favor do estabelecimento de programas de Estudos sobre Mulheres Negras, já que nem os Estudos sobre Negros, tampouco os Estudos sobre Mulheres, contemplavam as vivências e problemas das mulheres negras. Em especial, os trabalhos incluídos reafirmavam a importância do desenvolvimento de abordagens que dessem conta do caráter multifacetado e complexo das vivências de mulheres negras. 
Publicado um ano antes, This Bridge Called My Back, organizado por Cherrie Moraga e Gloria Anzaldua (1981), introduziu pioneiramente um novo marcador nessas vivências - a questão da etnia -, trazendo o testemunho, seja em forma de textos, cartas ou poesias, de mulheres latinas radicadas nos Estados Unidos e, em especial, latinas lésbicas, o que tornava essas vivências ainda mais multi-facetadas em termos de marcadores sociais imprimindo vulnerabilidades.

Dentre outros trabalhos igualmente importantes nessa linha, destacam-se, em particular, os de Patricia Hill Collins, uma socióloga negra norte-americana, que tem trazido importantes contribuições para se pensar opressões que se entrelaçam. Em Learning from the outsider within: The Sociological Significance of Black Feminist Thought, por exemplo, Collins (1991) ressalta a centralidade dessa noção para se dar conta da simultaneidade de opressões na vida cotidiana de mulheres negras, bem como para se pensar uma abordagem perspectivista de feministas negras. Já em Toward a new vision: race, class, and gender and categories of analysis and connection, Collins (1989) constrói uma crítica ao pensamento binário por trás de concepções de marcadores de opressão que se sobrepõem. Pensar a articulação de diferentes formas de opressão na perspectiva aditiva e dicotômica, segue a referida autora, também leva a se ranqueá-las em termos de importância. Em suas palavras:

Análises aditivas de opressão se sustentam igualmente nos pilares ou esse/ou aquele e da necessidade de quantificar e ranquear todas as relações para saber onde nos posicionamos. Essas abordagens tipicamente classificam as mulheres Afro-Americanas como mais oprimidas, vez que a maioria das mulheres negras vivencia os efeitos negativos das opressões de raça, classe e gênero simultaneamente. Em suma, quando se soma diferentes formas de opressão, se tem uma grande opressão que é maior que a soma de suas partes (COLLINS, 1989, p.5). 
Collins não nega que certos grupos experimentam instâncias de opressão muito mais opressivas, por assim dizer, do que outros. Por exemplo, ser linchada é muito pior do que ser tratada como objeto sexual. Contudo, ressalta ela, não se pode confundir a saliência de uma categoria de opressão sobre as outras na vida de uma pessoa, com posições teóricas quanto à natureza das opressões que se imbricam. E principalmente porque embora gênero, raça e classe estruturem a vida das pessoas, esses marcadores não são igualmente visíveis, tampouco têm importância igual na perspectiva de diferentes indivíduos. Para Collins, a natureza dessa imbricação, bem como com relação a que opressão poderá ter peso maior, irá variar de acordo com o contexto específico em questão.

Podemos concordar com Collins nesse ponto. Mas valeria aqui acrescentar que, se é verdade que as categorias gênero, raça, classe, idade/geração e outras mais estruturam a vida das pessoas, o nível de vulnerabilidade que a elas poderão atribuir dependerá da presença, ou não, de matrizes macroestruturais de opressão, a saber, sexismo, racismo, capitalismo (ou outro sistema econômico baseado em classes sociais hierarquizadas), etarismo, heteronormatividade, etc. Em outras palavras, por si só, as categorias gênero, raça, classe e outras semelhantes só expressam vulnerabilidades na presença das matrizes macroestruturais de opressão correspondentes. Ademais, são essas matrizes de opressão que se imbricam como resultado de processos históricos, podendo ou não se reproduzir em simbiose, tal qual na perspectiva de Heleieth Saffioti (1992) seria o caso do patriarcado, capitalismo e racismo.

Por exemplo, na história da Ciência Moderna, desigualdades de raça e de gênero foram construídas uma em relação a outra, usando-se as diferenças raciais para explicar a diferença de gênero e, ao mesmo tempo, as diferenças entre os sexos para explicar as desigualdades entre as supostas raças. Nesse processo, "[...] as raças 
'inferiores' passaram a representar o tipo 'feminino' da espécie humana, enquanto as mulheres tornaram-se a 'raça inferior' de gênero" (STEPAN, 1994, p.75). Nessa construção mútua, feita por analogias, racismo e sexismo tiveram, portanto, o respaldo da ciência moderna, sendo alimentados, conjuntamente, pelo sistema capitalista, ao tempo em que the forneceram, em contrapartida, mão de obra barata. Como bem ressaltou Heleieth Saffioti (1996, p.7): “[...] ao longo da história do patriarcado, este foi se fundindo com o racismo e, posteriormente, com o capitalismo, regime no qual desabrocharam, na sua plenitude, as classes sociais."

Há de se compreender, portanto, porque no panorama da história contemporânea, as lutas contra o racismo e contra o sexismo têm-se cruzado e se alimentado mutuamente (SARDENBERG, 2011). Isso aconteceu no século XIX, quando as primeiras feministas se empenharam nas campanhas abolicionistas e, novamente, nos anos 1960, quando o feminismo ressurgiu junto ao movimento negro, criando-se pontes entre um e outro movimento. Mais recentemente, as trajetórias entre as lutas contra as desigualdades de gênero e raça têm se cruzado nas ações no campo dos direitos humanos, demandando estratégias que possam trabalhar no sentido da conquista da igualdade de direitos para os negros e para as mulheres (CRENSHAW, 2002, p.173). Uma dessas importantes estratégias tem sido a abordagem das interseccionalidades de gênero, raça, classe e de outros marcadores sociais de diferenciação, conforme será discutido a seguir.

\section{OPRESSÕES QUE SE ENTRELAÇAM E INTERSECCIONALIDADES}

O conceito de "interseccionalidade", hoje empregado nos mais diversos contextos e assumindo diferentes conotações (DAVIS, 2008), é um importante instrumento analítico para se estudar, entender e responder às formas em que "[...] gênero intersecta com 
outras identidades e como essas intersecções operam em contextos determinados e contribuem na construção de experiências específicas de opressão e privilégios" (AWID, 2004, p.1).

Esse conceito foi originalmente utilizado pela advogada feminista negra, Kimberlé Crenshaw (1991), em um artigo onde procurava dar conta das violências específicas sofridas por mulheres negras, ganhando dimensão mais ampla a partir das discussões preparatórias à III Conferência Mundial contra o Racismo, a Discriminação Racial, Xenofobia e as Formas de Intolerâncias Correlatas da ONU (Durban, África do Sul, 2001), quando ficou constatada sua contribuição para a formulação e análise de políticas públicas. Conforme bem explicitou a referida autora:

A associação de sistemas múltiplos de subordinação tem sido descrita de vários modos: discriminação composta, cargas múltiplas, ou com dupla ou tripla discriminação. A interseccionalidade é uma conceituação do problema que busca capturar as conseqüências estruturais e dinâmicas da interação entre dois ou mais eixos da subordinação. Ela trata especificamente da forma pela qual o racismo, o patriarcalismo, a opressão de classe e outros sistemas discriminatórios criam desigualdades básicas que estruturam as posições relativas de mulheres, raças, etnias, classes e outras. Além disso, a interseccionalidade trata da forma como ações e políticas específicas geram opressões que fluem ao longo de tais eixos, constituindo aspectos dinâmicos ou ativos do desempoderamento (CRENSHAW, 2002, p.177).

Para dinamizar esse conceito, Crenshaw valeu-se da analogia das avenidas que se cruzam, afirmando que raça, gênero, classe, etnia, etc., operam como eixos de poder, constituindo "[...] as avenidas que estruturam os terrenos sociais, econômicos e políticos. É através delas que as dinâmicas de desempoderamento se movem" (CRENSHAW, 2002, p.177). Crenshaw observou, também, que, a depender do 
contexto, o "tráfego" pode ser muito mais intenso em umas avenidas e menos em outras, ou então, com um fluxo muito intenso em todas, como geralmente acontece no caso de "mulheres racializadas":

As mulheres racializadas frequentemente estão posicionadas em um espaço onde o racismo ou xenofobia, a classe e o gênero se encontram. Por consequência, estão sujeitas a serem atingidas pelo intenso fluxo de tráfego em todas essas vias. As mulheres racializadas e outros grupos marcados por múltiplas opressões, posicionadas nessas intersecções em virtude de suas identidades específicas, devem negociar o 'tráfego' que flui através dos cruzamentos. Esta se torna uma tarefa muito perigosa quando o fluxo vem simultaneamente de várias direções. Por vezes, os danos são causados quando o impacto vindo de uma direção lança vítimas no caminho do outro fluxo contrário; em outras situações, os danos resultam de colisões simultâneas" (CRENSHAW, 2002, p.177).

Tal perspectiva nos permite vislumbrar certas experiências de discriminação, de outra feita tornadas obscuras e invisíveis, porque estão justamente nos pontos de intersecção dos diferentes eixos de poder. Além disso, essa perspectiva transcende os limites das análises voltadas apenas para um desses eixos, vez que possibilita, também, reconhecermos e considerarmos nossas múltiplas identidades e as formas de discriminação que lhes são peculiares. De fato, ela aborda as diferentes posições sociais como relacionais, tornando visíveis as múltiplas posicionalidades que constituem a vida cotidiana e as relações de poder que as demarcam. Para tanto, torna-se necessário atentarmos, prioritariamente, para os pontos de intersecção, para a complexidade desse tecido interseccionado, para os processos dinâmicos em curso nesse tecer, e para as estruturas que definem nosso acesso a direitos e oportunidades. Ao mesmo tempo, a perspectiva exige um direcionamento de "baixo para cima" (bottom-up approach) 
nas análises e no planejamento (AWID, 2004, p.04). Segundo ressalta Crenshaw (2002, p.182):

[...] a atenção à subordinação interseccional exige uma estratégia que valorize a análise de baixo para cima, começando com o questionamento da maneira como as mulheres vivem suas vidas. A partir daí, a análise pode crescer, dando conta das várias influências que moldam a vida e as oportunidades das mulheres marginalizadas. É especialmente importante descobrir como as políticas e outras práticas podem moldar suas vidas diferentemente de como modelam as vidas daquelas mulheres que não estão expostas à mesma combinação de fatores enfrentados pelas mulheres marginalizadas.

Mas, concordo com Wendy Hulko (2009, p.45) em que, para melhor lidar com os efeitos das intersecções no cotidiano de mulheres, devemos trabalhar com o conceito de 'posicionalidade' junto ao de interseccionalidade, vez que esse último opera melhor em um nível teórico voltado para a “[...] maneira em que categorias identitárias interagem". Já posicionalidade indica o resultado dessa interação em termos de privilégios e desvantagens e funções, mais num nível prático, ou do cotidiano. Em especial, posicionalidade, se refere aos diferentes graus de privilégio e opressão que indivíduos detêm ou sofrem em função da intersecção de 'construtos identitários específicos', tais como raça, etnicidade, classe, gênero, orientação sexual, idade, etc. Ou seja, refere-se ao grau de vulnerabilidade de diferentes indivíduos em um determinado contexto. Todas (e todos) nós desfrutamos de privilégios e sofremos opressão de acordo com nossa posicionalidade relativa aos sistemas de opressão que se entrelaçam, tais como racismo, classismo, sexismo, etnocentrismo, e etarismo. O lugar específico que cada uma de nós ocupa em relação ao centro ou margem, ou seja, a nossa posicionalidade é determinada por nossas identidades - que são necessariamente interseccionadas 
(HULKO, 2009). Mas as nossas identidades não são fixas: elas mudam no tempo e espaço, portanto, nossa posicionalidade também muda de acordo. Dado que a posicionalidade não é uma categoria fixa, ela depende do contexto; logo, é sempre historicamente determinada, variando também a depender da fase de vida da pessoa.

Quando trabalhamos com os conceitos de posicionalidade e interseccionalidade, nos voltamos para rótulos socialmente designados baseados em processos de subordinação e dominação, enfatizando relações de poder desiguais. Contudo, é preciso considerar também questões referentes às identidades e subjetividades, pois, a maneira como as pessoas se identificam não é necessariamente a mesma em que são identificadas (HULKO, 2009). Quanto a isso, nos alerta também Avtar Brah (2006, p.371), se é certo que as “[...] identidades pessoais sempre se articulam com a experiência coletiva de um grupo, a especificidade da experiência de vida de uma pessoa esboçada nas minúcias diárias de relações sociais vividas produz trajetórias que não simplesmente espelham a experiência do grupo." Brah (2006, p.371) observa ainda que: "de maneira semelhante, identidades coletivas não são redutíveis à soma das experiências individuais".

Além disso, é preciso considerar que processos de racialização, tal como os de genderização e sexualização, também variam no tempo e no espaço e têm histórias distintas. "Racismos têm origem histórica diversa, mas se articulam com estruturas patriarcais de classe de maneiras específicas, em condições históricas dadas" (BRAH, 2006, p.352). Há também que se considerar os diferenciais de racialização em termos de 'espaços' distintos, vez que uma pessoa pode desfrutar de privilégios por ser percebida como 'branca' ou mais clara em um contexto e ser objeto de discriminação como uma pessoa 'negra' em outro (HULKO, 2009, p.49). Não custa ressaltar que raça e etnia devem ser consideradas separadamente, pois grupos étnicos ou de 
nacionalidades distintas podem ou não ser racializados a depender do contexto em questão (HULKO, 2009, p. 51).

Tais considerações me fazem lembrar pontos levantados por Julie Bettie (2000) sobre a questão de classe. Bettie verificou que em muitas análises as mulheres são tratadas como se não tivessem classe, pois a noção de 'classe trabalhadora' vem marcada como se fosse só branca e masculina. Dessa forma, as mulheres das classes trabalhadoras, em geral, as negras, em especial, se tornam invisíveis dentro da classe. De igual maneira, raça e classe acabam sendo muitas vezes vistas como variáveis categóricas, como se não fossem também construídas. No dizer de Bettie (2000, p.5): “Uma atenção mínima é dada às formas em que raça e classe são politicamente, historicamente e situacionalmente construídas (e performatizadas) em relação a gênero". Para Bettie (2000, p.10), assim como gênero, classe deve ser pensada não apenas em termos de uma 'posição material', mas também como 'performance', vez que a materialidade de classe inclui tanto recursos econômicos quanto culturais aos quais se atribui significados. É, pois, importante considerar as maneiras em que a subjetividade de classe, como uma identidade cultural, é vivenciada em relação aos significados culturais de raça, etnicidade, gênero e sexualidade.

Bettie estudou um grupo de jovens 'latinas' na California, observando que as jovens estudadas negociavam significados, fazendo performances de diferentes versões de feminilidade que “[...] eram integralmente ligadas e inseparáveis de suas performances de raça e classe" (2000, p.15). Com base nessas observações, Bettie ressalta que "raça e gênero não devem ser considerados apenas meras ideologias que mascaram a reprodução das desigualdades de classe, mas sim como princípios organizativos, processos que são cocriados com classe" (BETTIE, 2000, p.29).

Sem dúvida, o que vimos até agora nos leva a afirmar que, para abarcar a simultaneidade das matrizes e sistemas de opressão em 
toda sua complexidade, precisamos considerar os diferentes níveis de análise em jogo. Nesse tocante, as considerações de Patricia Hill Collins (1999) me parecem bastante pertinentes. Ela destaca como nível macro, estrutural, o nível das "opressões que se entrelaçam", que por sua vez conecta os diferentes sistemas de opressão. O segundo seria um nível dito 'micro', dos processos das interseccionalidades, com indivíduos ocupando posições sociais de acordo com as estruturas entrelaçadas de opressão. Para Collins, portanto, as categorias identitárias (raça, classe e gênero) se referem a sistemas de opressão, enquanto ao nível macro se têm as estruturas de opressão.

Em outro trabalho, Patricia Hill Collins (2000, p.277) destaca ainda quatro dimensões do poder que se entrelaçam para moldar a vida sócio-política-econômica, no caso, das mulheres negras, mas que poderíamos estender a todas as mulheres racializadas, a saber: 1) a dimensão estrutural que tem a ver com a maneira em que as instituições sociais estão organizadas de sorte a reproduzirem a subordinação das mulheres negras ao longo do tempo; 2) a dimensão disciplinar que realça o papel do Estado e de outras instituições que se apoiam em uma burocracia e na vigilância para regular as desigualdades; 3) uma dimensão hegemônica que lida com ideologia, cultura, conscientização; e, por fim, 4) uma dimensão interpessoal ao nível das interações sociais cotidianas. De acordo com Collins, manipulando a ideologia e a cultura, a dimensão hegemônica "[...] age como um link entre as instituições sociais (domínio estrutural) e suas práticas organizativas (domínio disciplinar) e o nível das interações sociais na vida cotidiana" (2000, p.284).

Por sua vez, trabalhando com as considerações de Collins, mas procurando melhor situá-las, Rita Dhamoon (apud HULKO, 2009) destaca quatro níveis de análise necessários para se dar conta desses múltiplos determinantes e das dimensões correspondentes. Primeiro, teríamos o nível das identidades, a exemplo de quando 
falamos de "mulheres asiáticas", "mulheres brasileiras", seguindose, como segundo, o das categorias sociais de diferenciação, ou seja, de raça, classe, gênero, sexualidade, etc. Em um terceiro nível se situariam os processos de racialização, sexualização e, no quarto e último, os sistemas correspondentes, tais como racismo, patriarcado, heteronormatividade. Nessa perspectiva, "interseccionalidades" se aplicaria a identidades e categorias (ou seja, primeiro e segundo níveis), enquanto a noção de "opressões que se entrelaçam", aos processos e sistemas (terceiro e quarto).

Analiticamente, poderíamos começar tanto com as pessoas e suas vivências, ou seja, com mulheres em situações sociais ou posicionalidades específicas, definidas pelas intersecções dos marcadores de diferenciação em um determinado contexto, quanto pela estruturação dos sistemas de opressão que ali se imbricam e põem em marcha os processos de racialização, sexualização, etc., que irão demarcar as vivências.

De toda sorte, ao trabalharmos com a perspectiva das opressões que se entrelaçam e das interseccionalidades, é bom ter em mente alguns pressupostos tal qual delineados por Ange-Marie Hancock (2007, p.251): 1) mais de uma categoria estará em jogo na análise de processos e problemas políticos complexos; 2) a relação entre essas categorias será uma questão aberta, para investigação empírica; 3) categorias de diferença são produções dinâmicas de indivíduos e fatores institucionais, sendo também simultaneamente contestadas e enfocadas nos planos individual e institucional de análise; 4) cada categoria implica em diversidade interna ao seu grupo. A perspectiva em questão demanda que examinemos seu entrecruzar em níveis diferentes de análise, não deixando de atentar para a 'complexidade causal'. Creio, porém, que tudo isso poderá ser melhor pensado a partir da metáfora dos prismas, mosaicos e caleidoscópios de gênero, objeto das minhas reflexões no que se segue. 


\section{Conclusão: SOBRE PRISMAS, MOSAICOS E CALEIDOSCóPIOS DE GÊNERO}

Quando completei oito anos ganhei de presente de aniversário um pequeno caleidoscópio que me fascinou. Era um brinquedo simples, de papelão, mas que podia prender minha atenção por um bom tempo, enquanto eu ia movimentando-o para a esquerda e direita e via uma nova figura, ou um novo mosaico, aparecer a cada movimento. Lembro-me que, para além da fascinação com os desenhos, fiquei curiosa para entender como aquilo funcionava e fui consultar o meu Tesouro da Juventude, uma enciclopédia para crianças e jovens (essencial para estudantes antes do aparecimento do 'Google'), que também ganhara de meu pai naquele aniversário. Lendo ali sobre o jogo de prismas e espelhos que se moviam para formar os mosaicos, passei a me interessar por prismas e os seus efeitos no jogo de luz. Houve até uma época em que tive prismas pendurados na janela do meu quarto para ver os desenhos que esse jogo fazia no teto.

Muitos anos mais tarde, quando escrevia um artigo sobre práticas e representações sobre a menstruação em sua diversidade, a imagem dos prismas, mosaicos e caleidoscópios me veio à mente (SARDENBERG, 1994). E, novamente, essas imagens surgiram em minha cabeça quando preparava minhas aulas para a disciplina "Dinâmica das Relações de Gênero, Raça e Classe" (que como este trabalho, também começou apenas como 'dinâmica de gêneroe classe'), oferecida por mim por vários anos em programas de pós-graduação da Faculdade de Filosofia e Ciências Humanas da Universidade Federal da Bahia. Mais recentemente, instada a participar de uma mesa em torno da questão das interseccionalidades de gênero, raça e classe, busquei na metáfora dos caleidoscópios um caminho para reunir minhas reflexões sobre as complexas articulações de gênero com outros marcadores, diferenciadores na dinâmica das relações sociais. Nesse intuito, encontrei a coletânea organizada por Joan Spade 
e Catherine Valentine (2008) que se valem da noção de "caleidoscópio de gênero", voltando-se para os prismas, padrões em jogo, bem assim como para as possibilidades de transformação de tudo isso.

Conforme delineei no início deste artigo, um caleidoscópio é um tubo que contem um arranjo de espelhos coloridos, ou de pequenos prismas que se articulam para produzir diferentes imagens ou mosaicos. Há também pedaços de vidro, ou conchas, por meio das quais a luz é refletida quando se olha pelo visor, criando os mosaicos que vão se transformando na medida em que movimentamos o tubo. As possibilidades de combinação são muitas, de sorte que raramente os mosaicos se repetem.

Spade e Valentine (2008) se servem dessa metáfora para pensar as múltiplas configurações de gênero quando intersectado, ou intersectando, outros marcadores de diferenciação social ou, segundo elas, outras categorias de diferença e desigualdade socialmente construídas. Elas identificam essas categorias como 'prismas sociais', afirmando que: "O conceito de prismas sociais nos ajuda a entender que gênero não é uma entidade universal ou estática, mas sim criada continuamente nos parâmetros sociais da vida individual e em grupo" (SPADE \& VALENTINE, 2008, p.xiii, tradução nossa). Conforme acrescentam essas autoras, gênero deve ser pensando como “[...] categorias, padrões, e expressões cuja relevância é contextualizada e sempre em mutação; a desigualdade de gênero não se constitui como um padrão social natural ou universal, mas sim como um dos vários sistemas de opressão, nenhum dos quais pode ser generalizado" (SPADE \& VALENTINE, 2008, p. xii).

Sem dúvida, é bom lembrar que gênero, raça e classe, ainda que compartilhando as mesmas feições como 'prismas sociais' ou marcadores que estabelecem divisões sociais, bem como sendo construídos por, ou entrecortados uns pelos outros, não podem nunca ser reduzidos uns aos outros. São, por assim dizer, categorias 
irredutíveis. Contudo, não custa repetir: se por um lado, tal como raça, classe ou sexualidade, gênero existe como uma categoria específica de identidade política e análise política, pensar gênero como um determinante que age por si só pode distorcer a realidade. "Gênero nunca opera de fato independente de outros aspectos da vida política, portanto é errôneo pensar gênero como uma categoria de análise autônoma" (YUVAL-DAVIS, 2007, p.229). A metáfora dos caleidoscópios nos ajuda a pensar gênero construindo e sendo construído, simultaneamente, pelos demais marcadores sociais que são tensionados em contextos específicos.

$\mathrm{Na}$ sua discussão sobre caleidoscópios de gênero, Spade e Valentine (2008) se referem à interação dos múltiplos prismas de diferenciação e desigualdade com o prisma de gênero, como constituinte de padrões de expressões e experiências gendradas. Contudo, prefiro pensar em termos de 'mosaicos' de gênero, criados pelas intersecções, sendo, pois, resultantes do entrelaçar das matrizes ou sistemas de opressão que, na nossa metáfora, constituiriam o próprio caleidoscópio.

Nessa concepção que ofereço, os mosaicos equivalem às 'posicionalidades' de gênero. E é precisamente aqui que a metáfora do caleidoscópio nos oferece os instrumentos para pensarmos a variação dessas posicionalidades no tempo e espaço, de uma forma mais fluida. Podemos pensar os movimentos do caleidoscópio nessas coordenadas de tempo e espaço, ora virando o caleidoscópio, seja para a direita e ver os mosaicos irem se transformando de acordo com espaços distintos e, para a esquerda, observando suas transformações, diga-se, ao longo do tempo.

Creio que o foco nos mosaicos/posicionalidades é particularmente relevante, pois eles correspondem ao lugar social que ocupamos em um determinado contexto e, assim, o que contorna as nossas vivências/experiências. É no plano dos mosaicos/ 
posicionalidades que se forjam também as nossas identidades 'possíveis' - e digo possíveis, vez que, a simultaneidade dos marcadores de diferença, ou de privilégios e vulnerabilidades, permite, por assim dizer, que nos identifiquemos mais com umas do que com outras de nossas múltiplas identidades possíveis. Por exemplo, em um estudo realizado com o sindicato de trabalhadoras domésticas de Salvador, Mary Castro observou que a identidade primeira dessas trabalhadoras foi a de classe, seguindo-se a de raça na medida em que se dava o crescimento do movimento negro na cidade (CASTRO, 1992). Mais recentemente, porém, essas trabalhadoras passaram a se identificar também enquanto 'mulheres negras', atuando nos movimentos de mulheres de Salvador (GONÇALVES, 2014).

Por último, quero chamar atenção para um artigo publicado recentemente sobre minhas 'aventuras antropológicas' fazendo trabalho de campo (SARDENBERG, 2014b), no qual fiz esse exercício de reflexão sobre minha 'posicionalidade' enquanto antropóloga feminista, movendo-me tanto em termos de contextos de campo distintos em que me vi trabalhando, isto é, no 'espaço', quanto ao longo do tempo. Em especial, procurei identificar e analisar, de que forma e em que medida, as intersecções de gênero, raça, etnia, classe, idade/geração, e sexualidade, dentre outras, dentro dos contextos etnográficos distintos no tempo e no espaço, em que atuei, demarcaram minha posicionalidade e persona no campo, promovendo - ou delimitando - meus encontros (ou desencontros) com meus interlocutores e interlocutoras na produção de um conhecimento antropológico e feminista. No artigo, não fiz uso da metáfora aqui referida, mas creio que poderia ter me sido muito útil para pensar essas experiências de campo em termos dos 'mosaicos' de gênero que as constituíram. Com isso quero dizer que as perspectivas aqui discutidas se aplicam não apenas para nosso melhor entendimento das vivências/experiências de gênero de nossas interlocutoras em nossos 
estudos, como também das nossas próprias vivências/experiências de gênero enquanto pesquisadoras.

\section{REFERÊNCIAS}

ARMSTRONG, Pat; ARMSTRONG, Hugh. Beyond Sexless Class and Classless Sex: Towards Feminist Marxism. Studies in Political Economy, no 10, Winter, 1983, p.7-41.

AWID: Association for Women's Rights in Development. Intersectionality: A Tool for Gender and Economic Justice. Women's Rights and Economic Change, no 9, 2004.

BARRETT, Michelle. Women's Oppression Today. Londres: Verso, NLB, 1980.

BARROS, Zelinda. Escola, racismo e violência. In: Projeto Gênero, Raça e Cidadania no Combate à Violência. Caderno para professores. Salvador: NEIM, UFBA, 2005, p. 35-39.

BEAUVOIR, Simone de. O Segundo Sexo. São Paulo: Nova Fronteira (volume único), 2009 [1949].

BEBEL, August. La mujer y el socialismo. Espanha: Akal Editor, 1977.

BETTIE, Julie. Women without class: chicas, cholas, trash, and the presence/absence of class identity. Signs: Journal of Women in Culture and Society. Vol. 26, nº 1, 2000, p.01-35.

BRAH, Avtar. Diferença, diversidade, diferenciação. Cadernos Pagu, n 26, 2006, p.329376.

BRITTO DA MOTTA, Alda. A Relação Impossível. In: HARDMAN, F. et al. Relações de Trabalho e relações de poder: mudanças e permanências. Fortaleza: Imprensa Universitária da UFCe, 1986, p.229-238.

BRITTO DA MOTTA, Alda. As dimensões de gênero e classe social na análise do envelhecimento. Cadernos Pagu, n ${ }^{\circ}$ 13, 1999, p.191-221.

BURNHAM, Linda; LOUIE, Miriam. The Impossible Marriage: A Marxist Critique of Socialist Feminism. Line of March, Spring, n 17, Special Issue, 1985.

BUTLER, Judith. Gender Trouble: feminism and the subversion of identity. Nova Iorque: Routledge, 1990.

CASTRO, Mary. Alquimia de categorias sociais na produção de sujeitos políticos. Revista Estudos Feministas, vol. 0, nº 0, Rio de Janeiro, 1992, p.57-73. 
COLLINS, Patricia Hill. Black feminist thought: knowledge, consciousness and the politics of empowerment. $2^{\text {nd }}$ ed. Nova Iorque: Routledge, 2000.

COLLINS, Patricia Hill. Fighting words. Black women and the search for justice.

Minneapolis: University of Minnesota Press, 1999, p. 201-228.

COLLINS, Patricia Hill. Learning from the Outsider Within: The Sociological

Significance of Black Feminist Thought. In: FONOW, M. M.; COOK, J. A. (Eds.). Beyond Methodology: Feminist Scholarship as Lived Research. Bloomington, Indiana: Indiana University Press, 1991, p.35-59.

COLLINS, Patricia Hill. Toward a new vision: race, class and gender as categories of analysis and connection. Memphis, Tenn: Center for Research on Women, Dept. of Sociology and Social Work, Memphis State, University,1989.

COMBAHEE RIVER COLLECTIVE. A black feminist statement. In: MORAGA, Cherrié; ANZALDÚA, Gloria (Eds.). This bridge called my back: writings by radical women of color. Berkeley, CA: Bookpeople (Kitchen Table), 1981, p. 210-218.

CONNELLY, Patricia. On Marxism and Feminism. In: HAMILTON, R; BARRETT, M. (Eds.). The Politics of Diversity. Londres: Verso, 1986, p.241-248.

CRENSHAW, Kimberlé. Documento para o encontro de especialistas em aspectos da discriminação racial relativos ao gênero. Revista Estudos Feministas, v.10, nº 1, 2002, p.171-189.

CRENSHAW, Kimberlé. Mapping the Margins: Intersectionality, Identity Politics, and Violence against Women of Color. Stanford Law Review, 1991, vol. 43, n 6, p. 1241-1299.

DAVIS, Kathy. Intersectionality as buzzword: a sociology of science perspective on what makes a feminist theory successful. Feminist Theory, vol. 9, no 1, 2008, p. 6785.

DIAS, Maria Odila Leite da Silva. Senhoras e ganhadeiras: elos na cadeia dos seres. In: DIAS, Maria Odila Leite da Silva. Quotidano e Poder em São Paulo no Século XIX. São Paulo: Brasiliense, 1984, p.83-113.

EISENSTEIN, Zillah R. Hacia el desarollo de una teoria de patriarcado capitalista y el feminismo socialista. In: EISENSTEIN, Zillah R. (Org.). Patriarcado Capitalista y Feminismo Socialista. Mexico, D.F: Siglo XXI, 1980, p.15-47.

ENGELS, Friederich. The Origin of the Family, Private Property and the State. Nova Iorque: International Publishers, 1972 [1884].

FEE, Elizabeth. The Sexual Politics of Victorian Social Anthropology. In: HARMAN, M; BANNER Lois W. (Eds.). Clio's Consciousness Raised. New 
Perspectives on the History of Women. Nova Iorque: Harper Colophon Books, 1974, p.86-102.

FIRESTONE, Shulamith. A Dialética do Sexo. São Paulo: Ed. Labor do Brasil, 1976 [1970].

GODELIER, Maurice. Parties mortes, idées vivantes dans la pensée de Marx sur les sociétés primitives. Marxisme et evolutionnisme. In: GODELIER, Maurice. Horizon, trajets marxistes en anthropologie, Tome I, Paris: Maspero, 1977.

GOLDMAN, Emma. The Traffic in Women. In: . Anarchism and Other Essays. Second Revised Edition. Nova Iorque \& Londres: Mother Earth Publishing Association, 1911, p. 183-200.

GONÇALVES, Terezinha. Crossroads of Empowerment: The Organization of Women Domestic Workers in Brazil. In: CORNWALL, A; EDWARDS, J. (Eds.). Feminisms, Empowerment and Development. Londres: Zed Books, 2014, p.210-227.

GUIMARÃES, Antonio Sérgio Alfredo. Como Trabalhar com “Raça” em Sociologia. Educação e Pesquisa, vol.29, no1, 2003, p.93-107.

HANCOCK, Ange-Marie. Intersectionality as a Normative and Empirical Paradigm. Politics and Gender, vol. 3, no2, 2007, p.248-253.

HARTMANN, Heidi. The Unhappy Marriage of Marxism and Feminism: Towards a More progressive union. Capital \& Class, vol. 8, 1979, p.1-33.

HIMMELWEIT, Susan. The Real Dualism of Sex and Class. Radical Review of Political Economy, vol. 16, no 1, 1984, p. 167-183.

HULKO, Wendy. The Time-and-Context-Contingent Nature of Intersectionality and Interlocking Oppressions. Affilia: Journal of Women and Social Work. Vol. 24, $\mathrm{n}^{\mathrm{o}} 1,2009$, p.44-55.

HULL, Gloria; SCOTT, Patricia; SMITH, Barbara (Eds.). But Some of Us Are Brave: All the Women Are White, All the Blacks Are Men: Black Women's Studies. Old Westbury, Nova Iorque: The Feminist Press, 1982.

KOWARICK, Lúcio. As Lutas Sociais e a Cidade: impasses e desafios. In: KOWARICK, Lúcio. (Ed.). As Lutas Sociais e a Cidade. São Paulo: Paz e Terra, 1988.

LEACOCK, Eleanor B. Introduction. In: ENGELS, F. The origin of the family, private property, and the state. Nova Iorque: International Publishers, 1972 [1884].

LERNER, Gerda. The creation of patriarchy. Oxford University Press, Inc: Nova Iorque, 1986. 
MACHADO NETO, Zahidé. As Meninas: sobre o trabalho da criança e da adolescente em família proletária. In: AGUIAR, N. (Org.). Mulheres na Força de Trabalho na América Latina: análises qualitativas, Petrópolis: Vozes, 1984, p.220-246.

MARX, Karl; KRADER, Laurence. The Ethnological Notebooks of Karl Marx. Assen: Van Gorcum, 1972.

MILLET, Kate. Política Sexual. México, DF: Aguillar Editores, 1975. [1971].

MITCHELL, Juliet. A mais longa revolução. Revista Civilização Brasileira, Ano III, no 14, São Paulo, 1967, p.05-41.

MORAGA, Cherríe; ANZALDUA, Gloria (Eds.). This Bridge Called my Back: Writings by Radical Women of Color. Nova Iorque: Kitchen Table, Women of Color Press,1981.

MORGAN, Lewis H. Ancient Society. Tucson, Arizona: University of Arizona Press, 1985 [1877].

PAOLI, Maria Célia. Os trabalhadores urbanos na fala dos outros. Tempo, espaço e classe na história operária brasileira. In: LOPES, J. S. Leite (Org.). Cultura e identidade operária. Rio de Janeiro: Museu Nacional/UFRJ; São Paulo: Marco Zero, 1987.

OAKLEY, Ann. Sex, gender and society. Nova Iorque: Harper, 1972.

PAOLI, Maria Célia; SADER, Éder. Sobre "classes populares" no pensamento sociológico brasileiro (notas de leitura sobre acontecimentos recentes). In:

CARDOSO, R. (Org.). A Aventura Antropológica. Rio de Janeiro: Paz e Terra, 1986.

ROWBOTHAM, Sheila. Caro Dr. Marx: carta de uma feminista socialista. Cadernos Pagu, no 32, jan.-jun. 2009 [1973], p.159-182.

RUBIN, Gayle. The Traffic in Women: Notes on the "political economy" of sex. In: REITER, R. (Ed.). Toward an Anthropology of Women. Nova Iorque: Monthly Review Press, 1975, p.157-210.

SACKS, Karen. Engels revisitado: a mulher, a organização da produção e a propriedade privada. In: ROSALDO, Michelle. Z.; LAMPHERE, Louise (Orgs.). A Mulher, a Cultura e a Sociedade. Rio de Janeiro: Paz e Terra, 1979, p.185- 206.

SAFFIOTI, Heleieth. A ontogênese do gênero. In: STEVENS, C.; SWAIN, T. (Orgs.). A construção dos corpos. Perspectivas feministas. Florianópolis: Editora Mulheres, 2008, p.149-181. 
SAFFIOTI, Heleieth. Quem tem medo dos esquemas patriarcais de pensamento? [1996] Disponível em: <http://www.araraquara.sp.gov.br/secretariagoverno/pagina_ indice. asp?iditem=195> Acesso em: 5 mar. 2006.

SAFFIOTI, Heleieth. Rearticulando gênero e classe social. In: BRUSCHINI, C.; COSTA, A. O. (Orgs.). Uma Questão de Gênero. Rio de Janeiro: Rosa dos Tempos; São Paulo: Fundação Carlos Chagas, 1992, p.183-215.

SARDENBERG, Cecilia. Migrações Perigosas: As (des)aventuras semânticas do conceito de gênero nos projetos e políticas para mulheres no Brasil. In: GONÇALVES, E. et al. (Orgs.). Iguais? Gênero, trabalho e lutas sociais. Goiânia: Ed. da PUC Goiás, 2014a, p.19-48.

SARDENBERG, Cecilia. Revisitando o campo: autocrítica de uma antropóloga feminista. Revista Mora, vol. 20, 2014b, p. 30-60.

SARDENBERG, Cecilia. A igualdade racial na perspectiva da interseccionalidade de gênero, raça e etnia. In: COSTA, A. A.; TEIXEIRA, A.; Vanin, I. (Orgs.). Ensino e gênero: perspectivas transversais. Salvador: NEIM,UFBa, 2011, p.75-88.

SARDENBERG, Cecilia. Classe, gênero e raça: lidando com diferenças e combatendo desigualdades. In: WATANABE, C. H.; CORREA, M. P. V.; ALMEIDA, R. (Org.). Identidades Culturais. 1a. ed., Recife, v. 1, 2001, p.23-36.

SARDENBERG, Cecilia. O gênero da memória: lembranças de operários e operárias. In: ALVES, I.; MACEDO, M.; PASSOS, E. (Orgs.). Metamorfoses: gênero e interdisciplinaridade. Salvador: NEIM/UFBA, 1998.

SARDENBERG, Cecilia. O Bloco do Bacalhau: protesto ritualizado de operárias na Bahia. In: Costa, A. A.; ALVES, I. (Orgs.). Ritos, Mitos e Fatos. Mulher e Relações de Gênero na Bahia. Salvador, Bahia: NEIM/FFCH/UFBA, 1997.

SARDENBERG, Cecilia. De sangrias, tabus e poderes: A menstruação em uma perspectiva transcultural. Revista Estudos Feministas, vol. 2, no 2, 1994, p.314-344.

SCOTT, Joan. Gender: a useful category of historical analysis. In: SCOTT, Joan. Gender and the politics of history. Nova Iorque: Columbia University Press, 1988, p.28-52.

SPADE, Joan Z.; VALENTINE, Catherine G. (Eds.). The kaleisdoscope of gender. Thousand Oaks, California: Pine Forge Press; Londres: Sage Publications, 2nd ed., 2008.

SOUZA-LOBO, Elisabeth; SOARES, Vera. Masculino e feminino na linha de montagem. In: SOUZA-LOBO, E. A classe operária tem dois sexos. São Paulo: Brasiliense, 1991, p.47-62. 
STEPAN, Nancy L. Raça e gênero o papel analogia na ciência. In: HOLLANDA, H. B. (Org.). Tendências e impasses: o feminismo como crítica da cultura. Rio de Janeiro: Rocco, 1994, p.72-96.

STOLCKE, Verena. O enigma das intersecções: classe, raça, sexo, sexualidade. A formação dos impérios transatlânticos do século XVI ao XIX. Revista Estudos Feministas, vol.14, no 1, 2006, p.15-42.

TERRAY, Emmanuel. Marxism and "primitive" societies. Nova Iorque: Monthly Review, 1972.

THOMPSON, Edward. The making of the English working class. Harmondsworth: Penguin, 3a. ed., 1980.

TRAVERSO-YÉPEZ, Martha A.; PINHEIRO, Verônica. Socialização de gênero e adolescência. Revista Estudos Feministas, vol. 13, nº 1, 2005, p.147-162.

TRUTH, Sojourney. Ain't I a Woman. [1851]. Disponível em: <http://legacy.fordham. edu/halsall/mod/sojtruth-woman.asp> Acesso em: 5 mar. 2014.

YUVAL-DAVIS, Nira. Intersectionality and Feminist Politics. European Journal of Women's Studies, vol. 13, nº 3, 2006, p.193-209. 